\title{
Insulin-like Growth Factor-I and Platelet-derived Growth Factor-BB Induce Directed Migration of Human Arterial Smooth Muscle Cells via Signaling Pathways That Are Distinct from Those of Proliferation
}

Karin E. Bornfeldt, * Elaine W. Raines, * Toru Nakano, Lee M. Graves, ${ }^{*}$ Edwin G. Krebs, ${ }^{\star}$ and Russell Ross *

Departments of * Pathology and ${ }^{\ddagger}$ Pharmacology, School of Medicine, University of Washington, Seattle, Washington 98195

\begin{abstract}
Directed migration or chemotaxis of arterial smooth muscle cells (SMC) contributes to intimal SMC accumulation, a key event in the development of atherosclerotic lesions and in restenosis after angioplasty. The present study compares and contrasts insulin-like growth factor I (IGF-I) and platelet-derived growth factor (PDGF-BB) as chemoattractants and mitogens for human arterial SMC. Compared with PDGF-BB, IGF-I is a weaker SMC mitogen. Thus, PDGF-BB, but not IGF-I, evokes a strong and rapid activation of mitogen-activated protein (MAP) kinase kinase and MAP kinase. However, IGF-I is a potent stimulator of directed migration of human arterial SMC, as measured in a Boyden chamber assay. The half-maximal concentration for migration is similar to the $K_{d}$ for IGF-I receptor interaction. An IGF-I receptor-blocking antibody blocks the effects of IGF-I, IGF-II, and insulin, indicating that the effects are indeed mediated through the IGF-I receptor. The maximal effect of IGF-I on directed migration ranges between $50 \%$ and $100 \%$ of the effect of PDGF-BB, the strongest known chemoattractant for SMC. The ability of IGF-I and PDGF-BB to induce chemotaxis coincides with their ability to stimulate phosphatidylinositol turnover, diacylglycerol formation, and intracellular $\mathrm{Ca}^{2+}$ flux and suggests that these signaling pathways, but not activation of the MAP kinase cascade, are required for chemotaxis of human arterial SMC. (J. Clin. Invest. 1994. 93:1266-1274.) Key words: chemotaxis • insulin-like growth factors - platelet-derived growth factor • signal transduction, smooth muscle
\end{abstract}

\section{Introduction}

Smooth muscle accumulation is a key event in the formation and progression of lesions of atherosclerosis and in restenosis after angioplasty and bypass surgery $(1,2)$. The accumulation of arterial smooth muscle cells (SMC) ${ }^{1}$ during lesion forma-

Dr. T. Nakano's current address is Shionogi Research Laboratories, Fukushima-ku, Osaka, Japan.

Address correspondence to Dr. Karin E. Bornfeldt, Department of Pathology, SM-30, University of Washington School of Medicine, Seattle, WA 98195.

Received for publication 6 April 1993 and in revised form 16 September 1993.

1. Abbreviations used in this paper: ERK, extracellular signal-regulated kinase; MAP, mitogen-activated protein (kinase); MBP, myelin basic protein; PDS, plasma-derived serum; PIP $_{2}$, phosphatidylinositol bisphosphate; PKI, protein kinase inhibitor; PLC, phospholipase C; SMC, smooth muscle cell(s).

J. Clin. Invest.

(C) The American Society for Clinical Investigation, Inc. 0021-9738/94/03/1266/09 \$2.00

Volume 93, March 1994, 1266-1274 tion is due to a combination of proliferation and directed migration of arterial SMC from the media into the intima $(3,4)$. Both of these activities can be stimulated by a number of regulatory polypeptides, produced within the lesion or derived from circulating cells. PDGF has been shown to be involved in the accumulation of SMC after balloon catheterization of the normal rat carotid artery in vivo (3), and is present in developing lesions of atherosclerosis (5). In vitro, PDGF-BB is a strong mitogen for arterial SMC (6), and PDGF is a potent inducer of directed migration of SMC (7-9).

Less interest has been focused on IGF-I in relation to a possible role in atherogenesis. The actions of IGF-I are generally mediated through the IGF-I receptor, although IGF-I interacts with the insulin receptor and the IGF-II receptor with lower affinity. In vitro studies show that IGF-I can be released by most cell types that contribute to atheroma formation, including arterial SMC, macrophages, and platelets (10-13). Arterial SMC express abundant IGF-I receptors, whereas expression of insulin receptors is low or absent (14). IGF-I expression is increased in the artery wall after balloon angioplasty (1517 ), and thus may play a potentially important role in the response of the vascular wall to injury.

The intracellular signaling pathways involved in cell movement and directed migration are obscure, and it is unclear whether they are similar or different from those required for cell proliferation. Reorganization of the cytoskeleton and adhesion of the cell to extracellular matrix components are probably of importance in the migratory response of a cell to a chemoattractant. Recent reports indicate links between the phosphatidylinositol pathway, actin fiber formation and cell migration (for review see references 18 and 19). Phosphatidylinositol turnover is stimulated by various chemoattractants $(20,21)$. Furthermore, stimulation of the phosphatidylinositol pathway does not seem to be absolutely required for proliferation induced by PDGF-BB (22). In contrast, activation of a signaling pathway involving the mitogen-activated protein (MAP) kinase, and the activator MAP kinase kinase, has been suggested to be of importance in PDGF-induced proliferation (23).

The aim of the present study was to determine whether IGF-I mediates chemotaxis of human arterial SMC, and to compare the relative effects of IGF-I with PDGF-BB, both of which have been implicated in atherogenesis. The possibility of distinct intracellular signaling pathways involved in chemotaxis versus proliferation also prompted investigation of some of the signaling events that follow activation of IGF-I and PDGF receptors.

\section{Methods}

Cell cultures. Human newborn ( $2 \mathrm{~d}$ to $3 \mathrm{~m}$ ) arterial SMC were obtained from the thoracic aortas of infants after accidental death, the sudden 
infant death syndrome, or congenital defects. Arterial SMC from adult thoracic aortas were obtained from normal donor heart transplants. The cells were isolated by the explant method and cultured as described previously (24). Cells were used in passages $2-10$, and were characterized as smooth muscle by morphologic criteria and by expression of smooth muscle $\alpha$-actin. The cells were negative in mycoplasma assays, and had a normal chromosome number. Three different strains (donors) of newborn aortic SMC and two different strains of adult aortic SMC were used with similar results.

Growth factors and peptides. Human recombinant IGF-I and IGFII were obtained from Upstate Biotechnology Inc. (UBI), Lake Placid, $\mathrm{NY}$, and human recombinant insulin was from Boehringer-Mannheim GmbH, Mannheim, FRG. Human recombinant PDGF-BB was kindly provided by Zymogenetics Inc., Seattle, WA, and human recombinant PDGF-AA was kindly provided by Hoffmann La Roche Inc., Basel, Switzerland. For binding studies, PDGF-BB and PDGF-AA were labeled with ${ }^{125}$ I to a specific activity of 340 and $3,400 \mathrm{cpm} / \mathrm{fmol}$, respectively, using Iodo-Beads ( Pierce Chemical Co., Rockford, IL). PDGFBB was modified with the Bolton-Hunter reagent (Pierce Chemical Co.) before iodination. ${ }^{125}$ I-IGF-I was obtained from Amersham International, Amersham, UK.

PKI peptide (a peptide inhibitor of cAMP-dependent protein kinase) was synthesized at the peptide synthesis facility, Howard Hughes Medical Institute, Seattle, WA. Recombinant rat extracellular signalregulated kinase (ERK-2) was a gift from Dr. M. Cobb, University of Texas, Austin, TX.

Migration assay. The migration and chemotaxis of cells were quantified using a 48-well micro-Boyden chamber apparatus (Neuroprobe Inc., Cabin John, MD). Growth factors were diluted in DME with $0.25 \%$ BSA and loaded into the lower wells of the Boyden chamber in triplicates. The wells were subsequently covered with a polyvinylpyrrolidone (PVP)-free filter with 8- $\mu \mathrm{m}$ pores (Nucleopore Corp., Pleasanton, CA ) coated with type I collagen (Vitrogen, Collagen Corp., Palo Alto, CA). Confluent cell cultures were washed four times in PBS and trypsinized (trypsin diluted 1:5 to a final concentration of $0.01 \%$ tryp$\sin / 0.11 \mathrm{mM}$ EDTA) for the minimum period of time required to obtain a monocellular suspension. The cells were washed twice in DME $/ 0.25 \% \mathrm{BSA}$, and resuspended at a density of 1 or 2 million cells/ $\mathrm{ml}$. Cells $(25,000$ or 50,000 cells in $50 \mu \mathrm{l})$ with or without growth factors were loaded into the upper wells of the Boyden chamber. The chambers were incubated for $4 \mathrm{~h}$ at $37^{\circ} \mathrm{C}$ in an atmosphere of $95 \%$ air $/ 5 \% \mathrm{CO}_{2}$.

In experiments performed with the specific IGF-I receptor blocking antibody, monoclonal $\alpha$ IR-3 (kindly provided by Dr. S. Jacobs, Wellcome Research Laboratories, Research Triangle Park, NC), cells were trypsinized and subsequently incubated for $30 \mathrm{~min}$ at $37^{\circ} \mathrm{C}$ with 1 or $10 \mu \mathrm{g} / \mathrm{ml} \alpha \mathrm{IR}-3$, or $10 \mu \mathrm{g} / \mathrm{ml}$ of a monoclonal nonblocking PDGF $\beta$-receptor antibody ( $\mathrm{pR}$ 7212) of the same subclass (IgG1), as a control. The cells were then loaded into the Boyden chamber and incubated in the absence or presence of growth factors and antibodies for 4 h. At the end of the incubation time, the cells attached to the filter were fixed and stained in Dif Quick stain (American Hospital Supply Corp., McGaw Park, IL). The migrated cells, on the lower side of the filter, were counted manually or by using a video image processing system (BioScan OPTIMAS, BioScan Inc., Edmonds, WA). Chemotaxis was calculated as the difference between the number of migrated cells in the presence (i.e., total migration) or absence (i.e., chemokinesis) of a concentration gradient of the chemoattractant.

Measurement of DNA synthesis. Cells were grown in 24-well trays and, when they reached $\sim 80 \%$ confluency, were changed to DME $/ 1 \%$ human PDS for $48 \mathrm{~h}$. After $48 \mathrm{~h}$, PDGF-BB, IGF-I or insulin was added, and the cells were incubated for an additional $18 \mathrm{~h}$ (PDGF-BB) or $12 \mathrm{~h}$ (IGF-I and insulin), and subsequently labeled with $2 \mu \mathrm{Ci} / \mathrm{ml}$ [ $\left.{ }^{3} \mathrm{H}\right]$ thymidine (New England Nuclear, Boston, MA) for $2 \mathrm{~h} .\left[{ }^{3} \mathrm{H}\right]-$ thymidine incorporation into DNA was measured as TCA-insoluble radioactivity. Initial experiments showed that the peak of DNA synthesis after PDGF-BB-stimulation occurred 18-20 h after addition, whereas the peak after stimulation with IGF-I occurred $12-14 \mathrm{~h}$ after addition of IGF-I.
PDGF and IGF-I binding studies. Binding of PDGF A or B-chain homodimers was performed as previously described (25). Confluent cells in 24-well trays were changed to DME with $1 \%$ human plasmaderived serum (PDS) for $48 \mathrm{~h}$ before initiation of experiments. Cells were washed in binding buffer, and subsequently incubated with ${ }^{125} \mathrm{I}$ PDGF-BB, ${ }^{125}$ I-PDGF-AA, or ${ }^{125}$ I-IGF-I for $3 \mathrm{~h}$ at $4^{\circ} \mathrm{C}$. Nonspecific binding of PDGF was defined as binding in the presence of $17 \mathrm{nM}$ unlabeled partially purified PDGF (PDGF-AB, -AA, and -BB) from outdated platelets, and nonspecific binding of IGF-I was defined as binding in presence of $100 \mathrm{nM}$ unlabeled IGF-I.

To compare the effects of trypsinization on PDGF and IGF-I binding site number and affinities, cells were treated exactly as for the migration assay, i.e., they were trypsinized (1:5 dilution of trypsin), plated in Vitrogen-coated 24-well trays, and were allowed to adhere for $30 \mathrm{~min}$ at $37^{\circ} \mathrm{C}$. In parallel, nontrypsinized cells in 24-well trays were assayed. Other experiments were set up to study whether IGF-I affects binding of PDGF-BB or PDGF-AA. Cells were preincubated with 1 $\mathrm{nM}$ IGF-I for 2 or $4 \mathrm{~h}$ at $37^{\circ} \mathrm{C}$, and binding studies performed as described above.

Inositol monophosphate accumulation and measurement of phosphatidylinositol and diacylglycerol lipid masses. For measurement of inositol monophosphate formation, cells in 6-well plates were incubated in DME/ $1 \%$ human PDS for $24 \mathrm{~h}$, and subsequently in Medium 199 (Gibco Laboratories, Grand Island, NY) with $1 \%$ PDS and $2 \mu \mathrm{Ci}$ / $\mathrm{ml}$ myo- $\left[{ }^{3} \mathrm{H}\right]$ inositol (Amersham International) for $24 \mathrm{~h}$ at $37^{\circ} \mathrm{C}$. Cells were washed three times in Medium 199, incubated for $24 \mathrm{~min}$ in the presence of $20 \mathrm{mM} \mathrm{LiCl}$, and thereafter stimulated with growth factors or vehicle at the indicated concentrations for $30 \mathrm{~min}$ at $37^{\circ} \mathrm{C}$. After $30 \mathrm{~min}, 100 \mu \mathrm{l}$ TCA $(100 \%)$ was added, the solubilized medium was extracted four times with ether, and neutralized extracts applied to BioRad Laboratories (Richmond, CA) 1-X8 AG columns (formate form, 100-200 mesh). After elution of unincorporated inositol and glycerophospho-derivates, inositol monophosphate was eluted in 0.2 $\mathrm{M}$ ammonium formate and $0.1 \mathrm{M}$ formic acid, and radioactivity was subsequently measured.

For measurements of phosphatidylinositol biphosphate $\left(\mathrm{PIP}_{2}\right)$ and diacylglycerol lipid mass, cells in $100 \mathrm{~mm}$-dishes were incubated in DME/1\% human PDS for $2 \mathrm{~d}$, and for an additional $12 \mathrm{~h}$ in DME without PDS or BSA. The cells were then stimulated with $10 \mathrm{nM}$ IGF-I or $1 \mathrm{nM}$ PDGF-BB. At the indicated times, the medium was removed and the lipids were extracted with ice-cold methanol. High-performance liquid chromatography analysis was performed with a $0.45 \times 25$ cm $\mu$-Porasil silica column (Waters Associates, Milford, MA) (26). The mobile phase consisted of a gradient of $1-9 \%$ water in hexane/ isopropanol $(3: 4, \mathrm{vol} / \mathrm{vol})$ run at a flow rate of $1 \mathrm{ml} / \mathrm{min}$. This was found to give adequate separation of diacylglycerol, phosphatidic acid, phosphatidylethanolamine, phosphatidylinositol, phosphatidylserine, phosphatidylcholine, and sphingomyelin. Lipids in column effluent were monitored at $260 \mathrm{~nm}$. The fractions were also analyzed for phosphorus content, amines, and acyl esters according to established methods $(27,28)$.

Measurement of intracellular calcium levels. Intracellular $\mathrm{Ca}^{2+}$ levels were measured according to Grynkiewicz et al. (29). In short, SMC were trypsinized and suspended in Hanks' medium/0.1\% BSA buffered with Hepes ( $\mathrm{pH} 7.4$ ), and subsequently incubated with $2 \mu \mathrm{M}$ Fura 2-acetoxymethylester for $1 \mathrm{~h}$ at room temperature. Fluorescence was measured as a $340 / 380 \mathrm{~nm}$ ratio after PDGF-BB or IGF-I stimulation of the cells in the presence or absence of $2 \mathrm{mM}$ EGTA at $37^{\circ} \mathrm{C}$ in a CAF-100 $\mathrm{Ca}^{2+}$ analyzer (JASCO, Tokyo, Japan).

Measurement of MAP-kinase and MAP-kinase kinase activity. Cells in 100-mm dishes ( $\sim 5$ million cells) were incubated in DME/ $1 \%$ human PDS for $2 \mathrm{~d}$. The cells were washed twice in DME/0.25\% BSA, and stimulated with growth factors for the indicated periods of time. Immediately after stimulation, the cells were washed twice in ice-cold PBS, once with buffer $\mathrm{H}$ containing $50 \mathrm{mM} \beta$-glycerophosphate, pH 7.4, $1.5 \mathrm{mM}$ EGTA, $0.1 \mathrm{mM} \mathrm{Na}_{3} \mathrm{VO}_{4}, 1 \mathrm{mM}$ DTT, 10 $\mu \mathrm{g} / \mathrm{ml}$ aprotinin, $5 \mu \mathrm{g} / \mathrm{ml}$ pepstatin, $20 \mu \mathrm{g} / \mathrm{ml}$ leupeptin, and $1 \mathrm{mM}$ benzamidine, scraped off the plates, and sonicated in $0.5 \mathrm{ml}$ buffer $\mathrm{H}$ for $20 \mathrm{~s}$. After sonication the cell extracts $(\sim 0.7 \mathrm{ml})$ were centrifuged 
at $100,000 \mathrm{~g}$ for $20 \mathrm{~min}$ at $4^{\circ} \mathrm{C}$ in a model TL-100 ultracentrifuge (Beckman Instruments, Inc., Fullerton, CA) and the supernatants $(\sim 1 \mathrm{mg}$ protein $/ \mathrm{ml})$ were saved for kinase assays.

Cell extracts $(5 \mu \mathrm{l})$ were assayed for MAP kinase activity in a solu-

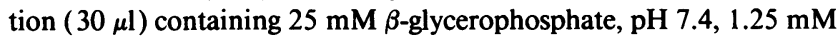
EGTA, $10 \mathrm{mM} \mathrm{MgCl}$, $0.5 \mathrm{mM}$ DTT, $0.15 \mathrm{mM} \mathrm{Na}_{3} \mathrm{Vo}_{4}, 2 \mu \mathrm{M}$ PKI peptide, $1 \mathrm{mg} / \mathrm{ml} \mathrm{BSA}, 10 \mu \mathrm{M}$ calmidizolium, $0.33 \mathrm{mg} / \mathrm{ml}$ myelin basic protein (MBP), and $0.1 \mathrm{mM}\left[\gamma-{ }^{32} \mathrm{P}\right] \mathrm{ATP}$ (sp act $700 \mathrm{cpm} /$ pmol), Du Pont-New England Nuclear). After incubation for $15 \mathrm{~min}$ at $30^{\circ} \mathrm{C}, 25 \mu \mathrm{l}$ was spotted onto $\mathrm{P}-81$ phosphocellulose paper (Whatman, Hillsboro, OR), washed several times in $150 \mathrm{mM}$ phosphoric acid and counted in $200 \mu \mathrm{l}$ of Ecolume scintillation fluid (ICN Biomedicals, Inc., Irvine, CA ). To calculate MAP kinase activity, samples incubated in the absence of MBP were subtracted from the same samples incubated in the presence of MBP.

For measurement of MAP kinase kinase, cell extracts were incubated at $4^{\circ} \mathrm{C}$ for $15 \mathrm{~min}$ with half a volume of Whatman DE-52 anion exchange resin equilibrated in buffer $\mathrm{B}$ ( $50 \mathrm{mM} \beta$-glycerophosphate, $1.5 \mathrm{mM}$ EGTA, $1.0 \mathrm{mM}$ DTT, and $\left.0.15 \mathrm{mM} \mathrm{Na}_{3} \mathrm{VO}_{4}\right)$. The DE-52 was removed by passing the sample over a small plug of glass wool. This pretreatment effectively removed all MAP kinase activity. MAP kinase kinase activity was measured by incubating DE- 52 incubated extracts with $50 \mathrm{ng}$ of recombinant ERK-2 in the assay buffer described above plus $0.1 \mathrm{mM}$ ATP. After incubation at $30^{\circ} \mathrm{C}$ for $15 \mathrm{~min}$, labeled 0.1 $\mathrm{mM}\left[\gamma^{-32} \mathrm{P}\right] \mathrm{ATP}$ ( $\mathrm{sp}$ act $700 \mathrm{cpm} / \mathrm{pmol}$ ) and $0.33 \mathrm{mg} / \mathrm{ml} \mathrm{MBP}$ were added and the reaction was allowed to proceed for an additional 10 $\min$. The reaction mixture was spotted onto P-81 paper and counted as described above. To calculate the MAP kinase kinase activity, samples incubated in the absence of ERK-2 were subtracted from those incubated in the presence of ERK-2. 1 U of MAP kinase kinase activity was defined as the amount of enzyme that activates 100 pmol of recombinant ERK-2 per $\mathrm{min} / \mathrm{ml}$ during the 15 -min incubation.

\section{Results}

$I G F-I, I G F-I I$, and insulin stimulate SMC migration via the IGF-I receptor. IGF-I stimulates migration and chemotaxis of

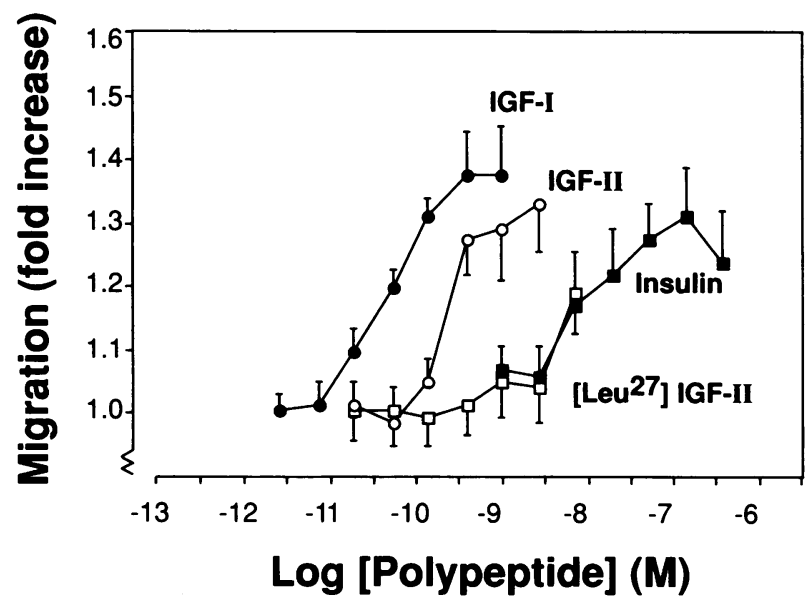

Figure 1. IGF-I induces migration of newborn human aortic SMC, and IGF-II, insulin and [ $\left.\mathrm{Leu}^{27}\right]$ IGF-II are less potent. Cells were incubated in DME containing 1\% human PDS for $48 \mathrm{~h}$, trypsinized, and incubated in a Boyden chamber for $4 \mathrm{~h}$ at $37^{\circ} \mathrm{C}$ in the presence or absence of the indicated concentrations of IGF-I, IGF-II, insulin $(n=6)$, or the IGF-II analogue [ $\mathrm{Leu}^{27}$ ]IGF-II $(n=5)$. Values are presented as -fold increase in migration as compared with cells exposed to vehicle (mean \pm SEM). The basal migration in the different experiments was $125 \pm 11$ (mean \pm SD of six replicates), $119 \pm 7$ cells $\times 200$ high-power field (HPF) $(25,000$ cells / well $)$ and $177 \pm 9$, $170 \pm 10,161 \pm 8$, and $105 \pm 9$ cells $\times 200 \mathrm{HPF}(50,000$ cells $/$ well $)$.

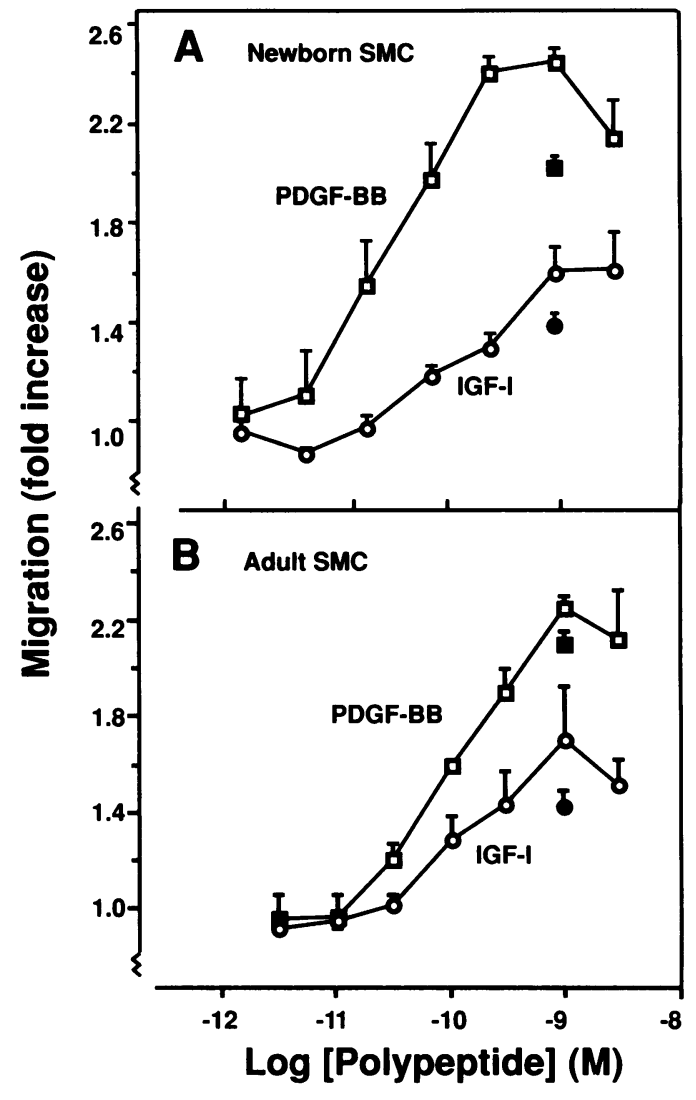

Figure 2. IGF-I and PDGF-BB induce migration of newborn and adult human arterial SMC. Migration studies with $(A)$ newborn and $(B)$ adult aortic SMC were performed as described in Fig. 1, with the indicated concentrations of growth factors. Values are presented as mean $\pm \operatorname{SEM}(A, n=4 ; B, n=3)$. The chemotactic response (filled symbols) was calculated by subtracting the number of migrated cells exposed to the same concentration of growth factor in the upper and lower well from the number of migrated cells exposed to growth factors only in the lower well (open symbols). The basal migration in the different experiments in $A$ was $68 \pm 9$ (mean \pm SD of six replicates), $57 \pm 9,55 \pm 8$, and $174 \pm 18$ cells $\times 200 \mathrm{HPF}$, and the basal migration in $B$ was $70 \pm 8,54 \pm 5$ and $58 \pm 14$ cells $\times 200 \operatorname{HPF}(25,000$ cells/well $)$.

human arterial SMC from both newborn and adult thoracic aorta (Figs. 1 and 2). The concentration of IGF-I required for half-maximal stimulation $\left(\mathrm{ED}_{50}\right.$ value) of migration and chemotaxis ranges between 0.08 and $0.2 \mathrm{nM}$, dependent on the strain of SMC. IGF-II and insulin induce increases in arterial SMC migration similar to IGF-I, but are 6 and 300 times less potent than IGF-I, respectively (Fig. 1). This is consistent with their affinities for the IGF-I receptor. Furthermore, the IGF-II analogue [ $\mathrm{Leu}^{27}$ ]IGF-II, which is highly specific for the IGF-II receptor at concentrations lower than $7 \mathrm{nM}(30)$, does not induce migration until concentrations that interact with the IGF-I receptor are used (Fig. 1). The maximal effect of IGF-I is not enhanced by IGF-II when tested over a wide interval of concentrations (data not shown).

To further examine the receptor that mediates IGF-I, IGFII, and insulin-induced migration we utilized an IGF-I receptor blocking antibody, $\alpha$ IR-3. This antibody was able to block the migratory response to IGF-I, as well as to IGF-II and insulin (Fig. 3). It did not, however, block the migratory or chemokinetic response to PDGF-BB (Table I). 


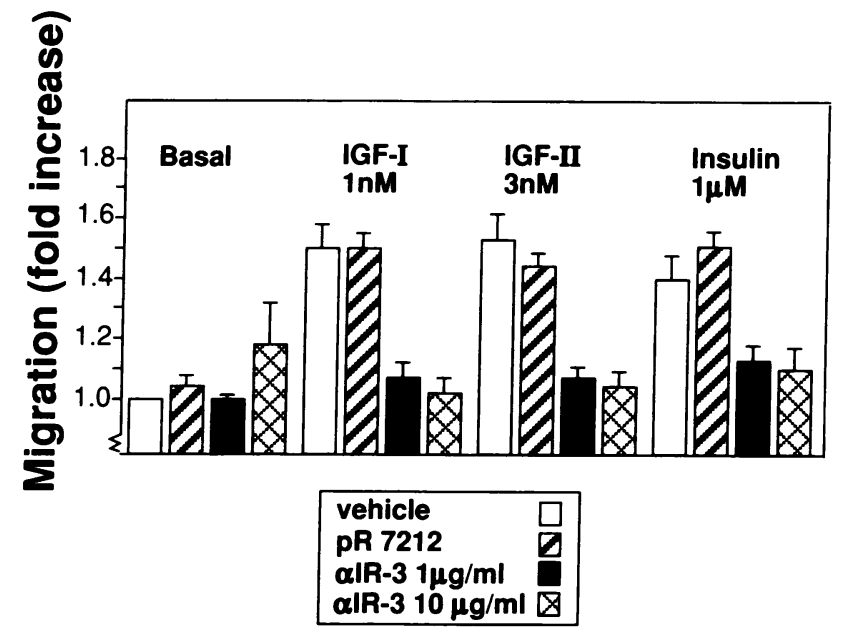

Figure 3. The effects of IGF-I, IGF-II, and insulin are mediated through the IGF-I receptor. Newborn aortic SMC were trypsinized and incubated in the presence or absence of 1 or $10 \mu \mathrm{g} / \mathrm{ml}$ of the IGF-I receptor blocking antibody, $\alpha \mathrm{IR}-3$, or $10 \mu \mathrm{g} / \mathrm{ml}$ of a nonblocking PDGF $\beta$-receptor antibody (pR 7212) of the same subclass for $30 \mathrm{~min}$ at $37^{\circ} \mathrm{C}$. The cells were subsequently incubated in the Boyden chamber with or without antibodies and polypeptides at the indicated concentrations. Values are presented as mean $\pm \operatorname{SEM}(n=4)$. The basal migration in the different experiments was $278 \pm 18$ (mean \pm SD of six replicates), $335 \pm 35,71 \pm 11$, and $120 \pm 13$ cells $\times 200 \mathrm{HPF}$ $(50,000$ cells/well $)$.

Comparison of chemotactic and growth-promoting effects induced by IGF-I and PDGF-BB. When tested in the same experiments, IGF-I is typically able to induce $\sim 50 \%$ of the maximal migratory effect observed with PDGF-BB. Similar migratory responses to IGF-I and PDGF-BB were observed with arterial SMC obtained from newborn thoracic aorta (Fig. $2 A$ ), as compared with adult thoracic aorta (Fig. $2 B$ ). In one strain (newborn) the effect of IGF-I was comparable to the maximal effect observed with PDGF-BB (the maximal-fold increase in migration induced by IGF-I was $1.62 \pm 0.09$ and by PDGF-BB was $1.72 \pm 0.08, n=4)$.

To determine whether IGF-I increases migration by modulation of PDGF receptor numbers or affinities, binding studies

Table I. IGF-I Receptor Antibodies Inhibit IGF-I-induced, but Not PDGF-BB-induced Migration

\begin{tabular}{lcccc}
\hline \multicolumn{1}{c}{ Treatment } & $\begin{array}{c}\text { No } \\
\text { addition }\end{array}$ & $\begin{array}{c}\mathrm{pR} 7212 \\
(10 \mu \mathrm{g} / \mathrm{ml})\end{array}$ & $\begin{array}{c}\alpha \mathrm{IR}-3 \\
(1 \mu \mathrm{g} / \mathrm{ml})\end{array}$ & $\begin{array}{c}\alpha \mathrm{IR}-3 \\
(10 \mu \mathrm{g} / \mathrm{ml})\end{array}$ \\
\hline \multicolumn{5}{c}{ number of cells/ $\times 20$} \\
IGF-I migh power field \\
IGF-I chemokinesis & $64 \pm 4$ & $60 \pm 14$ & $14 \pm 4$ & $10 \pm 3$ \\
PDGF-BB migration & $37 \pm 4$ & $38 \pm 5$ & $6 \pm 5$ & $4 \pm 4$ \\
PDGF-BB chemokinesis & $116 \pm 15$ & $100 \pm 11$ & $107 \pm 15$ & $124 \pm 18$ \\
& $36 \pm 7$ & $40 \pm 8$ & $36 \pm 10$ & $40 \pm 12$
\end{tabular}

Newborn aortic SMC were trypsinized and incubated in the presence or absence of 1 or $10 \mu \mathrm{g} / \mathrm{ml}$ of the IGF-I receptor blocking antibody $\alpha \mathrm{IR}-3$, or $10 \mu \mathrm{g} / \mathrm{ml}$ of a nonblocking PDGF $\beta$-receptor antibody (pR 7212) of the same subclass for $30 \mathrm{~min}$ at $37^{\circ} \mathrm{C}$. The cells were subsequently incubated in the Boyden chamber with or without antibodies and $1 \mathrm{nM}$ IGF-I or $1 \mathrm{nM}$ PDGF-BB. Values are presented as number of cells $/ \times 200$ high-power field above basal migration (mean \pm SEM, $n=3$ ). with ${ }^{125}$ I-PDGF-BB and -PDGF-AA were performed. Neither $\alpha$ - nor $\beta$-receptor number, nor receptor affinities $\left(K_{\mathrm{d}}\right)$ were affected by a 2 or $4 \mathrm{~h}$ of preincubation with $1 \mathrm{nM}$ IGF-I (data not shown).

PDGF-BB strongly induces DNA synthesis, whereas IGF-I evokes a lower response, reaching $\sim 20 \%$ of the response evoked by PDGF-BB (Fig. 4). Furthermore, whereas the maximal concentration of PDGF-BB is approximately the same for migration and DNA synthesis $\left(\mathrm{ED}_{50}=0.05\right.$ and $0.08 \mathrm{nM}$, respectively), concentrations of IGF-I required to stimulate DNA synthesis are 5-10 times higher, as compared with stimulation of migration $\left(\mathrm{ED}_{50}=1 \mathrm{nM}\right.$ and $0.08-0.2 \mathrm{nM}$, respectively). Insulin is 60 times less potent than IGF-I in stimulating DNA synthesis, with a maximal response at $1 \mu \mathrm{M}$ (Fig. 4). IGF-II stimulates DNA synthesis to a maximal level similar to that of IGF-I, but the $\mathrm{EC}_{50}$ value is approximately three times higher (data not shown). Similar results on DNA synthesis are obtained when the growth factors are added in the absence of $1 \%$ human PDS to minimize the possible contribution of plasma IGF-I and IGF-binding proteins. The stimulation of DNA synthesis by PDGF-BB is reflected by an $\sim 40 \%$ increase in cell number $3 \mathrm{~d}$ after addition of PDGF-BB ( $1 \mathrm{nM}$ ), whereas cell number is not significantly increased $3 \mathrm{~d}$ after stimulation with $10 \mathrm{nM}$ IGF-I (data not shown).

$I G F-I, P D G F-B B$, and PDGF-AA binding sites and affinities. The SMC cells used (newborn) express $\sim 15,000$ high-affinity $\left(K_{\mathrm{d}} \sim 0.1 \mathrm{nM}\right)$ binding sites for IGF-I (Fig. $5 A$ ). This is in the same order of magnitude as the number of PDGF receptor $\alpha$-subunits (Fig. $5 B$ ), but $\sim 15$ times lower than the expression level of high affinity $\left(K_{\mathrm{d}}=0.1 \mathrm{nM}\right)$ binding sites for PDGF-BB (Fig. $5 C$ ). High-affinity binding of $\left[{ }^{125} \mathrm{I}\right](\mathrm{A} 14)$ monoiodinated human insulin (Amersham International) could not be detected in several independent experiments. To investigate the effect of the trypsinization procedure used for the migration assay on the different receptors, cells were treated exactly as for migration studies, and the number and affinities of binding sites were compared with nontrypsinized cells. Trypsinization does not affect binding of IGF-I (Fig. $5 A$ ), whereas the binding of both PDGF-AA and PDGF-BB was about half of that observed in nontrypsinized cells (Fig. 5, $B$ and $C$ ). This is likely to be due to a decreased number of binding sites, since the affinities of the high affinity binding sites are not significantly affected by trypsinization as estimated with Scatchard plots (inserts, Fig. 5, $B$ and $C$ ).

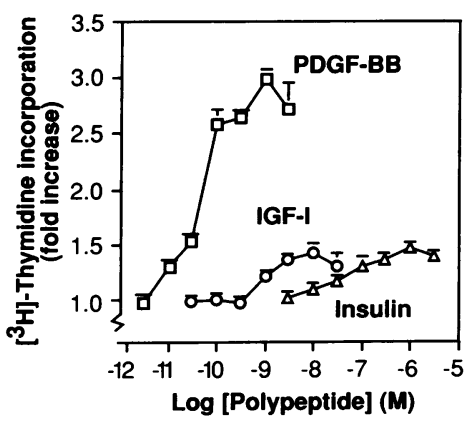

Figure 4. PDGF-BB is a more efficient mitogen than IGF-I in human arterial SMC cells. Newborn human cells were kept in DME/1\% human PDS for $2 \mathrm{~d}$ before the experiments. The cells were stimulated for $18 \mathrm{~h}$ with PDGF-BB or for $12 \mathrm{~h}$ with IGF-I or insulin, and then pulse labeled with $\left.2 \mu \mathrm{Ci} / \mathrm{ml} \mathrm{[}{ }^{3} \mathrm{H}\right]-$ thymidine for $2 \mathrm{~h}$. DNA synthesis was measured as TCA-insoluble radioactivity. The values are presented as mean $\pm \mathrm{SD}$ of three different experiments (each experiment performed with triplicate samples at each point). Basal $\left[{ }^{3} \mathrm{H}\right]-$ thymidine incorporation was $25.5 \pm 3.6 \mathrm{cpm} / \mu \mathrm{g}$ protein. 

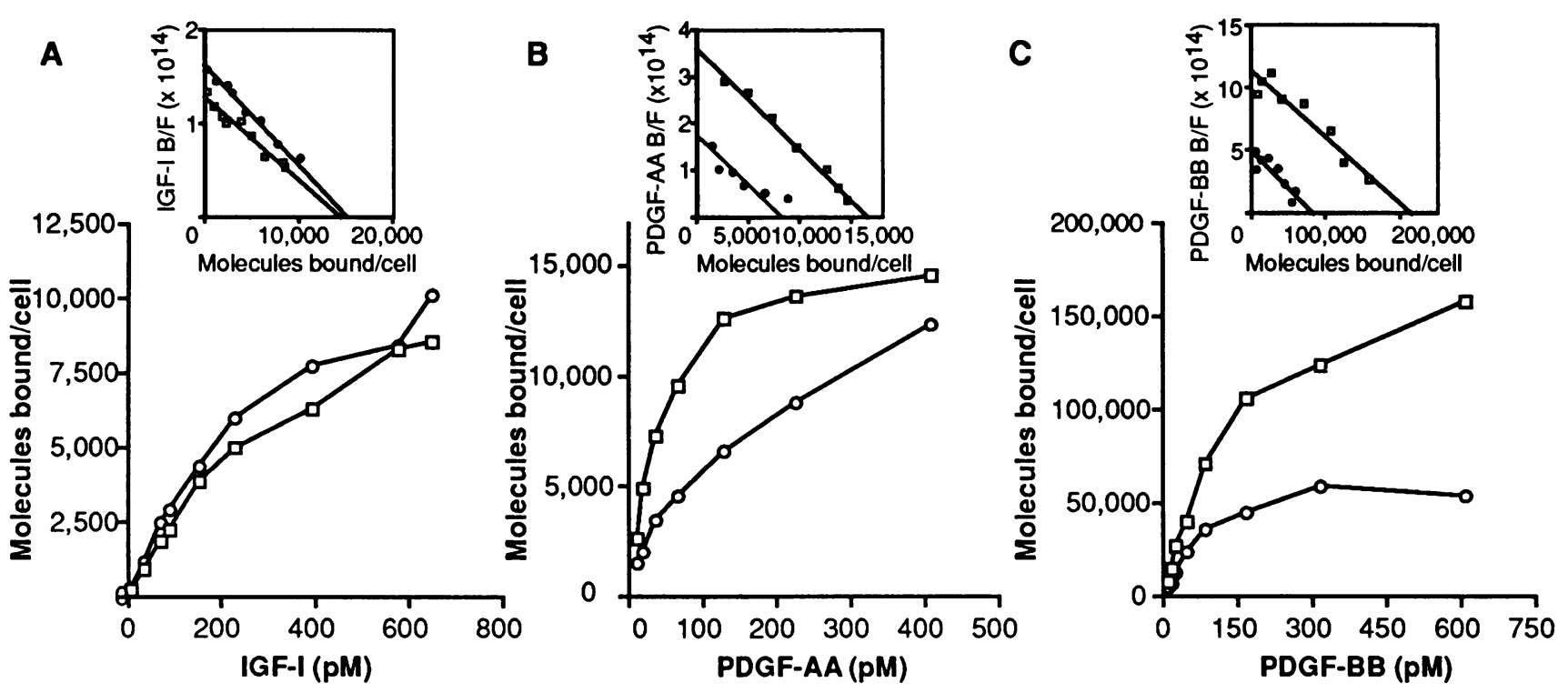

Figure 5. Measurements of high-affinity binding of IGF-I, PDGF-AA and PDGF-BB on human newborn arterial SMC: effects of trypsinization. Confluent cell cultures were incubated in DME/1\% human PDS for $2 \mathrm{~d}$ before the experiment. Binding of $(A){ }^{125} \mathrm{I}-\mathrm{IGF}-\mathrm{I},(B){ }^{125} \mathrm{I}-\mathrm{PDGF}-\mathrm{AA}$, or $(C)^{125}$ I-PDGF-BB was measured after a 3-h incubation at $4^{\circ} \mathrm{C}$. Nonspecific binding was defined as binding in the presence of $100 \mathrm{nM}$ unlabeled IGF-I or $17 \mathrm{nM}$ unlabeled partially purified PDGF. The experiments were repeated two to four times with different cells and passage numbers. Scatchard plots (inserts) were used to estimate number and affinities of specific binding sites (B/F is expressed as B/F per cell). Attached cells $(\square)$ have 14,400 high-affinity IGF-I binding sites $/$ cell $\left(K_{\mathrm{d}}=0.11 \mathrm{nM}\right), 17,100$ high-affinity PDGF-AA binding sites $/$ cell $\left(K_{\mathrm{d}}=50\right.$ $\mathrm{pM})$, and 215,500 high-affinity PDGF-BB binding sites/cell $\left(K_{\mathrm{d}}=0.19 \mathrm{nM}\right)$. The reattached cells $(O)$ have 15,200 high-affinity IGF-I binding sites/cell $\left(K_{\mathrm{d}}=0.09 \mathrm{nM}\right), 8,100$ high-affinity PDGF-AA binding sites/cell $\left(K_{\mathrm{d}}=40 \mathrm{pM}\right)$ and 84,500 high-affinity PDGF-BB binding sites/cell $\left(K_{\mathrm{d}}=0.17 \mathrm{nM}\right)$.

Ability of IGF-I and PDGF-BB to induce chemotaxis correlates with their ability to stimulate phosphatidylinositol turnover, diacylglycerol formation, and intracellular calcium release. Both PDGF-BB and IGF-I stimulate inositol monophosphate formation in newborn aortic SMC. The concentrations of IGF-I and PDGF-BB required to stimulate inositol monophosphate formation are similar to the concentrations that stimulate chemotaxis ( Table II and Fig. 2). The increased inositol monophosphate formation is reflected by an early (maximal effect $15-45 \mathrm{~s}$ after stimulation) increase in diacylglycerol

Table II. PDGF-BB and IGF-I Stimulate Inositol Monophosphate Formation in Newborn Human Aortic SMC

\begin{tabular}{lc}
\hline & $\begin{array}{c}\text { Inositol monophosphate } \\
\text { formation }\end{array}$ \\
\hline & $c p m /$ well \\
Vehicle & $294 \pm 106$ \\
PDGF-BB $(0.1 \mathrm{nM})$ & $1066 \pm 115$ \\
PDGF-BB $(1 \mathrm{nM})$ & $2331 \pm 387$ \\
IGF-I $(0.1 \mathrm{nM})$ & $733 \pm 184$ \\
IGF-I $(1 \mathrm{nM})$ & $1098 \pm 251$
\end{tabular}

Inositol monophosphate formation was measured in cells incubated in $2 \mu \mathrm{Ci} / \mathrm{ml}$ myo- $\left[{ }^{3} \mathrm{H}\right]$ inositol in Medium 199 containing $1 \%$ human PDS in six-well trays for $24 \mathrm{~h}$. Phosphatidylinositol turnover was blocked with $20 \mathrm{mM} \mathrm{LiCl}$ for $24 \mathrm{~min}$, and the cells subsequently stimulated with growth factors for $30 \mathrm{~min}$ at $37^{\circ} \mathrm{C}$. Cells were extracted with TCA and free inositol monophosphate was eluted from a BioRad 1-X8 AG column. The results are shown as cpm/well $(700,000-800,000$ cells $)$, mean $\pm \operatorname{SEM}(n=4)$. formation and a reciprocal decrease in $\mathrm{PIP}_{2}$ lipid mass after stimulation by either IGF-I or PDGF-BB (Fig. 6, $A$ and $B$ ). Neither PDGF-BB, nor IGF-I affect phosphatidylcholine or phosphatidylethanolamine lipid mass over the studied period of time (data not shown). Stimulation of phosphatidylinositol turnover by IGF-I and PDGF-BB is associated with an increased intracellular $\left[\mathrm{Ca}^{2+}\right]$ as shown by Fig. 7. Subnanomolar concentrations of either IGF-I or PDGF-BB stimulate $\mathrm{Ca}^{2+}$-release, with a maximal effect reached $10-40 \mathrm{~s}$ after stimulation (Fig. $7 \mathrm{~A}$ ). The $\mathrm{EC}_{50}$ values of IGF-I and PDGF-BB, as esti-

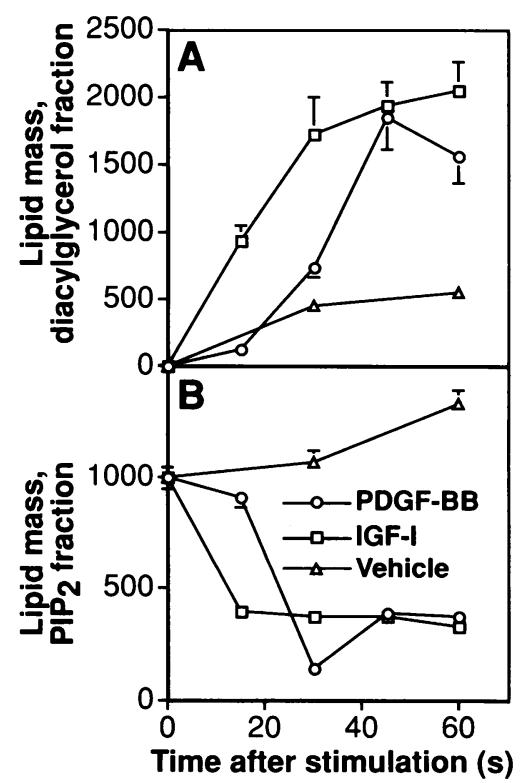

Figure 6. IGF-I and PDGF-BB induce increases in diacylglycerol lipid mass and reciprocal decreases in PIP lipid mass. Newborn $\mathrm{SMC}$ in $100-\mathrm{mm}$ dishes were stimulated with $10 \mathrm{nM}$ IGF-I, $1 \mathrm{nM}$ PDGF-BB or vehicle ( $10 \mathrm{mM}$ acetic acid/ $0.25 \%$ BSA) for the indicated periods of time. (A) Diacylglycerol mass and $(B) \mathrm{PIP}_{2}$ lipid mass were measured using high-performance liquid chromatography. The results are presented as mean \pm SD of triplicate samples. The experiment was repeated twice with similar results. 
A

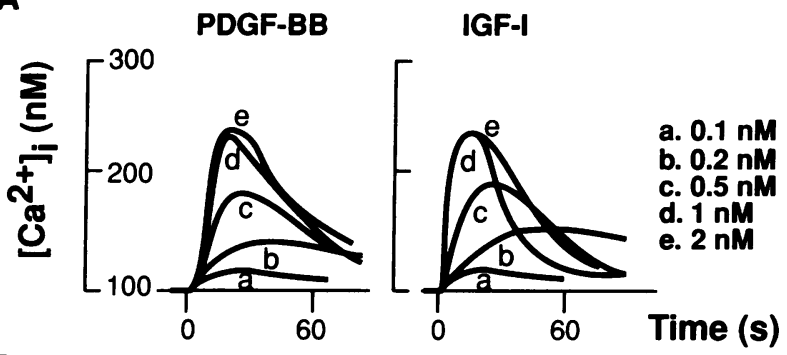

B

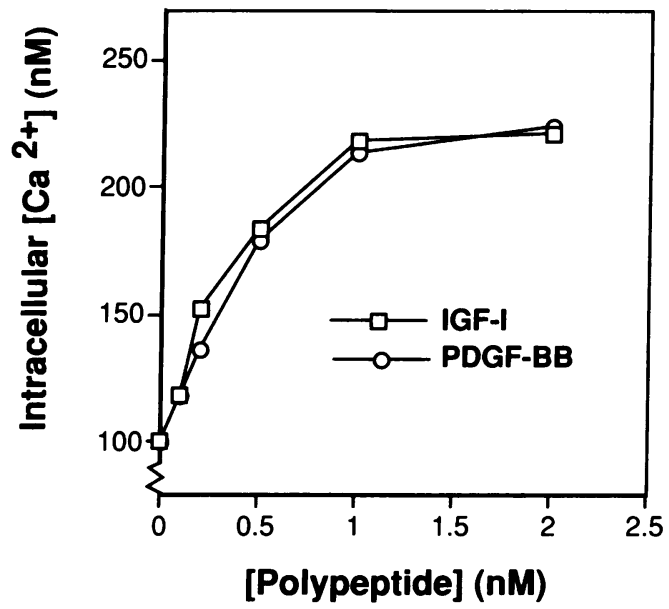

Figure 7. IGF-I and PDGF-BB induce calcium mobilization in human arterial SMC. Newborn cells were preloaded with fura-2 acetoxymethylester for $1 \mathrm{~h}$ at room temperature, washed and stimulated with indicated concentrations of PDGF-BB or IGF-I at $37^{\circ} \mathrm{C}$. The $340 / 380 \mathrm{~nm}$ ratio of emitted fluorescence was measured in a CAF$100 \mathrm{Ca}^{2+}$-analyzer. The resting intracellular $\left[\mathrm{Ca}^{2+}\right]$ level was $105 \pm 2$ nM. Representative effects of IGF-I and PDGF-BB (of four different experiments) on $(A) \mathrm{Ca}^{2+}$-transients and $(B)$ dose-response curves of intracellular $\mathrm{Ca}^{2+}$ levels are shown.

mated from the dose-response curves, are 0.27 and $0.38 \mathrm{nM}$, respectively (Fig. $7 \mathrm{~B}$ ). The rise in intracellular $\left[\mathrm{Ca}^{2+}\right]$ is likely due to release from intracellular compartments, since both IGF-I and PDGF-BB give rise to similar $\mathrm{Ca}^{2+}$ transients in the presence of 2 mM EGTA (data not shown).

$P D G F-B B$, but not IGF-I, is a strong activator of the MAP kinase cascade. The pattern of responses to PDGF-BB versus IGF-I is quite different when activation of MAP kinase kinase or MAP kinase are assessed. PDGF-BB ( $1 \mathrm{nM}$ ) evokes a marked activation of both MAP kinase and MAP kinase kinase, whereas $10 \mathrm{nM}$ IGF-I does not (Figs. 8 and 9). Activation of MAP kinase kinase and MAP kinase is maximal 5 min after addition of PDGF-BB, and the time course of activation of MAP kinase kinase shows a more rapid decrease in activity compared with MAP kinase. Dose-response curves reveal that the $\mathrm{ED}_{50}$ values for PDGF-BB activation of both MAP kinase $\left(\mathrm{ED}_{50}=0.12 \mathrm{nM}\right)$ and MAP kinase kinase $\left(\mathrm{ED}_{50}=0.11 \mathrm{nM}\right)$ are similar to the $K_{\mathrm{d}}$ of receptor binding (Fig. 9). IGF-I has little effect on MAP kinase kinase and MAP kinase within a broad range of concentrations in cells adherent to plastic as shown in Fig. 9, nor are they significantly activated when the cells are plated under conditions used for the migration studies. Similar effects are observed when a specific synthetic peptide (ST1) RRRELVEPLTPSGEAPN ( the MAP kinase phosphor-

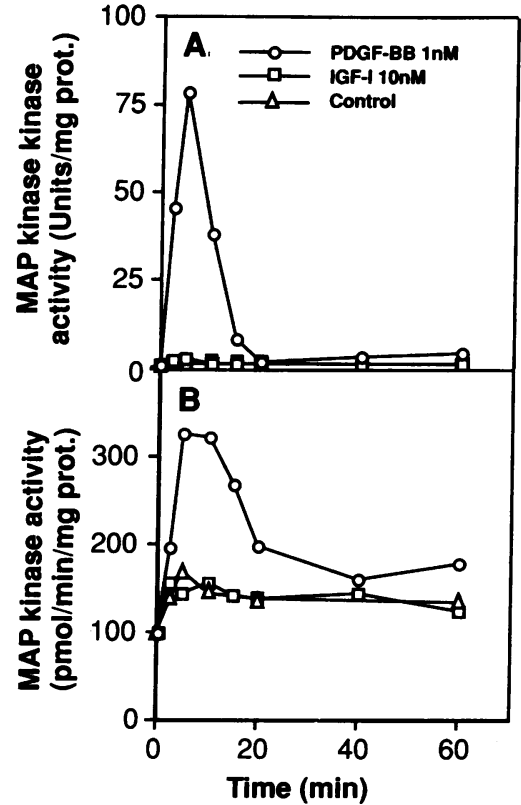

Figure 8. PDGF-BB, but not IGF-I, evokes a rapid and strong activation of MAP kinase kinase and MAP kinase in human arterial SMC.

Newborn human cells were incubated in DME/1\% human PDS for $2 \mathrm{~d}$, washed, and stimulated with $1 \mathrm{nM}$ PDGF-BB or $10 \mathrm{nM}$ IGF-I in DME/0.25\% BSA for the indicated periods of time. $(A)$ For measurement of MAP kinase kinase activity, cell lysates were precleared on a DE-52 mini column, and phosphorylation of myelin basic protein by activated recombinant ERK-2 was measured. ( $B$ ) MAP kinase activity was measured as phosphorylation of myelin basic protein during a $15-\mathrm{min}$ incubation at $30^{\circ} \mathrm{C}$. The results are expressed as mean of duplicate samples (the mean variation within duplicates was $9.1 \%$ in $A$ and $6.3 \%$ in $B$ ). The lower MAP kinase activity at $t$ $=0$ in the presented experiment $(B)$ is due to variation within the duplicates, and was not consistently found to be lower than basal or IGF-I-stimulated samples.

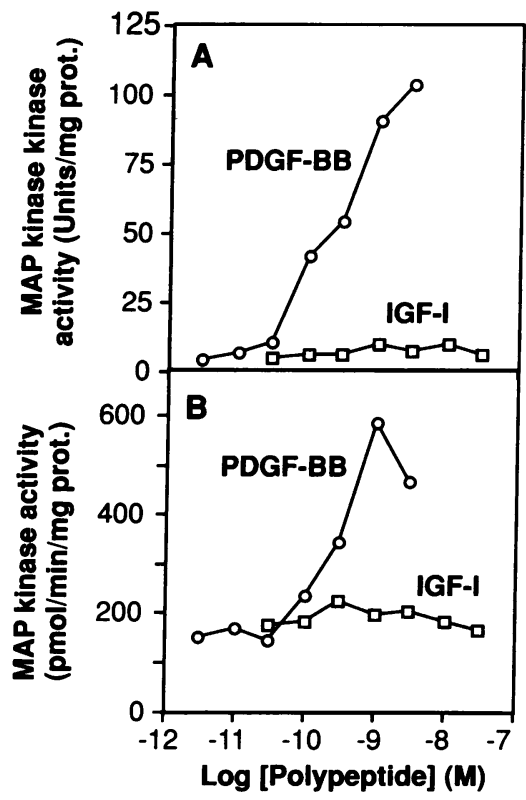

Figure 9. PDGF-BB is a potent activator of MAP kinase kinase and MAP kinase in human arterial SMC. Newborn human cells were incubated in DME/ $1 \%$ human PDS for $2 \mathrm{~d}$, washed, and stimulated with PDGF-BB or IGF-I in DME/0.25\% BSA for 5 min at $37^{\circ} \mathrm{C}$. For measurement of MAP kinase kinase activity $(A)$, cell lysates were precleared on a DE-52 mini column, and phosphorylation of myelin basic protein by activated recombinant ERK-2 was measured. MAP kinase activity $(B)$ was measured as phosphorylation of myelin basic protein during a $15-\mathrm{min}$ incubation at $30^{\circ} \mathrm{C}$. The results are expressed as mean of duplicate samples (the mean variation within duplicate samples was $9.5 \%$ in $A$ and $8.4 \%$ in $B$ ). Experiments were repeated at least twice using cells from different passages. 
ylation site is underlined) is used instead of MBP as a MAP kinase substrate. Furthermore, 10 nM IGF-I demonstrates no significant MBP phosphorylating activity after separation of the samples on a Mono-Q column (Pharmacia, Uppsala, Sweden ).

In contrast to IGF-I, PDGF-AA ( $1 \mathrm{nM})$ evokes a marked activation of MAP kinase kinase and MAP kinase after 5 min, comparable to half-maximal activation by PDGF-BB (data not shown). Although the number of PDGF receptor $\beta$-subunits (which bind only PDGF B-chain) are significantly greater than the number of PDGF receptor $\alpha$-subunits (which bind PDGF A- or B-chain) or IGF-I receptors, the number of IGF-I and PDGF receptor $\alpha$-subunits are very comparable (Fig. 5). To verify that the increased phosphorylation of MBP after PDGFBB stimulation is due to activation of MAP kinases, samples were separated on a Mono-Q column, and fractions containing MBP phosphorylating activity were analysed by immunoblotting using an antibody (7884E) against the MAP kinases. The antibody was raised in a rabbit against the peptide ITVEEALAHPYLEQYYDPTDE, which represents residues 307-327 of the ERK gene product. Western blots showed the presence of both ERK-1 and ERK-2 in fractions containing MBP phosphorylating activity. Activation by PDGF-BB was demonstrated as a shift in migration in the gel (data not shown).

\section{Discussion}

The IGF-I receptor mediates SMC chemotaxis. The present study shows that IGF-I is a potent stimulant of directed migration, or chemotaxis, of both newborn and adult human aortic SMC obtained from several donors. IGF-II and insulin are able to induce the same maximal migration, although they are 6 and 400 times less potent than IGF-I, respectively. In previous studies on different cell lines, IGF-II was reported to be able to stimulate migration through both the IGF-I receptor (31) and the IGF-II receptor (32). The present study demonstrates that the effect of IGF-II is not additive with that observed with IGF-I and that the effects of IGF-I, IGF-II and insulin can each be blocked with the IGF-I receptor specific antibody, $\alpha$ IR-3. To further investigate the effect of IGF-II, an IGF-II analogue ([ $\left.\mathrm{Leu}^{27}\right]$ IGF-II), highly selective for the IGF-II receptor (30), was used. [ $\mathrm{Leu}^{27}$ ]IGF-II is $\sim 60$ times less potent than native IGF-II as a stimulant of SMC migration. Taken together, the results strongly suggest that the migratory effect of IGF-I is mediated through the IGF-I receptor and, when present in sufficient concentrations, IGF-II and insulin stimulate migration of human arterial SMC via cross-reaction with the IGF-I receptor.

IGF-I has been shown to stimulate migration of epithelial cells and endothelial cells (33-36), rat periodontal ligament fibroblastic cells (37), and some human malignant cell lines $(31,38,39)$. These data, together with the results of the present study, show that IGF-I can act as a chemoattractant for various types of epithelial and mesenchymal cells.

Stimulation of SMC migration by IGF-I and PDGF-BB. The level of SMC migration induced by IGF-I ranges between $50 \%$ and $100 \%$ of the maximal response obtained with PDGF, the strongest chemoattractant for arterial SMC described to date. The chemotactic effect of IGF-I has recently been shown to be of a similar magnitude as that of PDGF-BB in another mesenchymal cell type; rat periodontal ligament fibroblastic cells (37). The lower maximal effect of IGF-I we observed compared to PDGF-BB may result from the lower number of high affinity binding sites for IGF-I on these cells. Although PDGF-BB binding sites are decreased after the trypsinization procedure used for migration studies, the number is still about five times higher than for IGF-I. Further support for this interpretation comes from the observation in a single isolate of newborn SMC in which PDGF-BB and IGF-I induced a similar maximal migratory response, in which the number of PDGFBB binding sites is $\sim 40 \%$ of that observed in the strain shown in Fig. $2 A$. Regardless, IGF-I is a potent chemoattractant for cultured human arterial SMC.

The potential importance of migration in lesion formation has been highlighted by in vivo studies implicating PDGF in the neointima that forms in the rat carotid artery within 2 wk after balloon angioplasty. In vivo administration of anti-PDGF antibody after balloon injury of the rat carotid decreases intimal accumulation of SMC by $>40 \%$ with no decrease in the labeling index in the neointima or the media in the time window of labeling examined (3). These studies, together with gentle injury studies in which PDGF was administered to the injured rat carotid artery (4), suggest that the effect of PDGF on intimal thickening may result primarily from stimulation of SMC migration from the media into the intima. Migration stimulated by IGF-I may also contribute to this accumulation.

Intracellular signaling pathways involved in chemotaxis versus proliferation. The signal transduction pathways from the PDGF and IGF-I receptors, and the molecular mechanisms required to stimulate chemotaxis versus proliferation are not completely understood. Recent studies have shown that phosphoinositides bind several actin-binding proteins, and indicate that phosphatidylinositol turnover may be associated with the cytoskeletal reorganization required for chemotaxis $(40,41$; for review see 18,19). We, therefore, asked whether phosphatidylinositol turnover may be involved in the chemotactic response of SMC. Indeed, both PDGF-BB and IGF-I were found to stimulate phosphatidylinositol turnover, diacylglycerol formation and intracellular $\mathrm{Ca}^{2+}$-release.

PDGF-BB-induced phosphatidylinositol turnover is likely to involve activation of phospholipase $\mathrm{C}_{\gamma}\left(\mathrm{PLC}_{\gamma}\right)$ after association of src homology 2 ( $\mathrm{SH} 2$ ) domains in PLC $\gamma$ with specific phosphorylated tyrosine residues in the carboxy-terminal portion of the PDGF $\beta$-receptor (22). PDGF $\beta$-receptor mutants lacking the PLC $\gamma$-binding tyrosine residues are able to induce the same maximal mitogenic response as the wild-type receptor, suggesting that activation of PLC $\gamma$ is not an absolute prerequisite for PDGF induced proliferation (22), although redundant signaling pathways from the PDGF receptor $\beta$-subunit that lead to mitogenesis most likely exist (42).

The mechanism of IGF-I-induced phosphoinositol turnover is less clear, but may, under some circumstances, involve activation of PLC $\beta$ rather than PLC $\gamma(43)$. In many cell lines, IGF-I does not induce inositol trisphosphate formation, and one of the IGF-I receptor signaling mediators (insulin receptor substrate 1) does not appear to bind $\mathrm{SH} 2$-fusion proteins containing $\mathrm{PLC} \gamma-\mathrm{SH} 2$ domains in vitro (44). However, in some primary cell types, such as cardiac myocytes and thyroid cells, IGF-I stimulates inositol trisphosphate formation $(45,46)$. The mechanism of IGF-I-induced phosphatidylinositol turnover in SMC remains to be elucidated.

The mitogenic effects of various growth factors, acting through tyrosine kinase receptors, may be dependent on activation of a pathway involving p21 Ras and the MAP kinase 
cascade ( 47 , reviewed in reference 48 and references therein). The present study shows that in human arterial SMC, PDGFBB is a potent mitogen and a strong activator of the MAP kinase cascade, whereas IGF-I is not. Taken together, these results suggest that activation of MAP kinase, after PDGF receptor activation, is involved in PDGF-BB mitogenic signaling whereas our results further imply that activation of the MAP kinase pathway is not required for chemotaxis of human SMC.

In contrast to the present study, IGF-I has been reported to activate MAP kinase signaling in other cell types (49), and insulin is known to activate the MAP kinase cascade $(50,51)$. The lack of effect of IGF-I in the SMC may very well be cell type specific, and does not reflect a low IGF-I receptor number, since PDGF-AA gives a marked activation of the MAP kinase cascade, despite similar receptor numbers. The effects of IGF-I on SMC DNA synthesis may, at least in part, be due to activation of intracellular pathways distinct from the MAP kinase pathway. This is in line with the observation that mitogenic effects of PDGF and IGF-I are additive in SMC (52).

The present study shows a correlation of the ability of IGF-I and PDGF-BB to induce phosphatidylinositol turnover, diacylglycerol formation, and $\mathrm{Ca}^{2+}$-release from intracellular compartments during chemotaxis of human arterial SMC. In contrast, IGF-I does not share the potency of PDGF-BB to activate the MAP kinase cascade and induce SMC proliferation. Further studies will be required to establish the extent of the differences in signaling pathways involved in chemotaxis versus proliferation.

\section{Acknowledgments}

The authors are grateful to Dr. Stuart L. Bursten, Cell Therapeutics Inc., Seattle, WA for the measurements of $\mathrm{PIP}_{2}$ and diacylglycerol lipid masses. We also thank Dr. Steven Jacobs (Burroughs Wellcome Co.) for the generous supply of the IGF-I receptor blocking antibody $\alpha$ IR-3 and Dr. Ron G. Rosenfeld (Stanford University, Stanford, CA) for [ $\mathrm{Leu}^{27}$ ] IGF-II. We acknowledge Dr. Tim Bird (Immunex Corp., Seattle, WA) for initial MAP kinase assays and discussions during the course of this work. The excellent technical assistance of Li-Chuan Huang and Karen Engel is gratefully acknowledged.

The study was supported in part by grants from the National Heart, Lung, and Blood Institute of the National Institutes of Health, grants HL- 18645 and HL-03174 to Drs. Ross and Raines, grants DK 42528 and GM 42508 from the National Institute of Health, and a grant from the Muscular Dystrophy Association to Dr. Krebs. Dr. Bornfeldt is supported in part by a grant from the Swedish Medical Research Council and a postdoctoral fellowship from the Swedish Society for Medical Research.

\section{References}

1. Ross, R. 1993. The pathogenesis of atherosclerosis: a perspective for the 1990s. Nature (Lond.). 362:801-809.

2. Clowes, A. W., and S. M. Schwartz. 1985. Significance of quiescent smooth muscle migration in the injured rat carotid artery. Circ. Res. 56:139-145.

3. Ferns, G. A. A., E. W. Raines, K. H. Sprugel, A. S. Motani, M. A. Reidy, and $R$. Ross. 1991. Inhibition of neointimal smooth muscle accumulation after angioplasty by an antibody to PDGF. Science (Wash. DC). 253:1129-1132.

4. Jawien, A., D. F. Bowen-Pope, V. Lindner, S. M. Schwartz, and A. W. Clowes. 1992. Platelet-derived growth factor promotes smooth muscle cell migration and intimal thickening in a rat model of balloon angioplasty. J. Clin. Invest. 89:507-511.

5. Ross, R., J. Masuda, E. W. Raines, A. M. Gown, S. Katsuda, M. Sasahara, L. T. Malden, H. Masuko, and H. Sato. 1990. Localization of PDGF-B protein in macrophages in all phases of atherogenesis. Science (Wash. DC). 248:10091012.
6. Raines, E. W., D. F. Bowen-Pope, and R. Ross. 1990. Peptide growth factors and their receptors. In Handbook of Experimental Pharmacology. M. B. Sporn and A. B. Roberts, editors. Volume 951. Springer-Verlag, Inc., New York. 173-262.

7. Grotendorst, G. R., H. E. J. Seppä, H. K. Kleinman, and G. R. Martin. 1981. Attachment of smooth muscle cells to collagen and their migration toward platelet-derived growth factor. Proc. Natl. Acad. Sci. USA. 78:3669-3672.

8. Grotendorst, G. R., T. Chang, H. E. J. Seppä, H. K. Kleinman, and G. R. Martin. 1982. Platelet-derived growth factor is a chemoattractant for vascular smooth muscle cells. J. Cell. Physiol. 113:261-266.

9. Ferns, G. A. A., K. H. Sprugel, R. A. Seifert, D. F. Bowen-Pope, J. D. Kelly, M. Murray, E. W. Raines, and R. Ross, R. 1990. Relative platelet-derived growth factor receptor subunit expression determines cell migration to different dimeric forms of PDGF. Growth Factors. 3:315-324.

10. Clemmons, D. R. 1985. Variables controlling the secretion of a somatomedin-like peptide by cultured porcine smooth muscle cells. Circ. Res. 56:418426.

11. Delafontaine, P., H. Lou, and R. W. Alexander. 1991. Regulation of insulin-like growth factor I messenger RNA levels in vascular smooth muscle cells. Hypertension. 18:742-747.

12. Rom, W. N., P. Basset, G. A. Fells, T. Nukiwa, B. C. Trapnell, and R. G. Crystal. 1988. Alveolar macrophages release an insulin-like growth factor I-type molecule. J. Clin. Invest. 82:1685-1693.

13. Karey, K. P., and D. A. Sirbasku. 1989. Human platelet-derived mitogens. II. Subcellular localization of insulin-like growth factor I to the $\alpha$-granule and release in response to thrombin. Blood. 74:1093-1100.

14. King, G. L., A. D. Goodman, S. Buzney, A. Moses, and C. R. Kahn. 1985. Receptors and growth-promoting effects of insulin and insulin-like growth factors on cells from bovine retinal capillaries and aorta. J. Clin. Invest. 75:1028-1036.

15. Cercek, B., M. C. Fishbein, J. S. Forrester, R. H. Helfant, and J. A. Fagin 1990. Induction of insulin-like growth factor I messenger RNA in rat aorta after balloon denudation. Circ. Res. 66:1755-1760.

16. Bornfeldt, K. E., H. J. Arnqvist, and L. Capron. 1992. In vivo proliferation of vascular smooth muscle in relation to diabetes mellitus, insulin-like growth factor I and insulin. Diabetologia. 35:104-108.

17. Khorsandi, M. J., J. A. Fagin, D. Giannella-Neto, J. S. Forrester, and B. Cercek. 1992. Regulation of insulin-like growth factor-I and its receptor in rat aorta after balloon denudation. Evidence for local bioactivity. J. Clin. Invest. 90:1926-1931.

18. Stossel, T. P. 1993. On the crawling of animal cells. Science (Wash. DC). 260:1086-1094.

19. Aderem, A: 1992. Signal transduction and the actin cytoskeleton: the roles of MARCKS and profilin. Trends Biochem. Sci. 17:438-443.

20. Kohn, E. C., L. A. Liotta, and E. Schiffmann. 1990. Autocrine motility factor stimulates a three-fold increase in inositol trisphosphate in human melanoma cells. Biochem. Biophys. Res. Commun. 166:757-764.

21. Verghese, M. W., L. Charles, L. Jakoi, S. B. Dillon, and R. Snyderman. 1987. Role of a guanine nucleotide regulatory protein in the activation of phospholipase $C$ by different chemoattractants. J. Immunol. 138:4374-4380.

22. Rönnstrand, L., S. Mori, A.-K. Arvidsson, A. Eriksson, C. Wernstedt, U. Hellman, L. Claesson-Welsh, and C.-H. Heldin. 1992. Identification of two C-terminal autophosphorylation sites in the PDGF $\beta$-receptor: involvement in the interaction with phospholipase C $\gamma$. EMBO (Eur. Mol. Biol. Organ.) J. 11:39113919.

23. Pazin, M. J., and L. T. Williams. 1992. Triggering signaling cascades by receptor tyrosine kinases. Trends Biochem. Sci. 17:374-378.

24. Ross, R., and B. Kariya. 1980. Morphogenesis of vascular smooth muscle in atherosclerosis and cell culture. In Handbook of Physiology: The cardiovascular System II. Circulation, Vascular Smooth Muscle. D. F. Bohr, A. P. Somlyo, and H. V. Sparks, editors. American Physiological Society, Bethesda, MD. 69-91.

25. Bowen-Pope, D. F., and R. Ross. 1985. Peptide hormones. In Hormone Action Part I. Methods Enzymol. 109:69-100.

26. Bursten, S. L., W. E. Harris, K. Bomsztyk, and D. Lovett. 1991. Interleukin-1 rapidly stimulates lysophosphatidate acyltransferase and phosphatidate phosphohydrolase activities in human mesangial cells. J. Biol. Chem. 266:20732-20743.

27. Kronberg, A., and W. E. Pricer. 1953. Enzymatic estrification of $\alpha$-glycerophosphate by long chain fatty acids. J. Biol. Chem. 204:345-357.

28. Keenan, A. W., G. Schmidt, and T. Tanaka. 1968. Quantitative determination of phosphatidylethanolamine and other phosphatides in various tissues of the rat. Anal. Biochem. 23:555-558.

29. Grynkiewicz, G., M. Poenie, and R. Y. Tsien. 1985. A new generation of $\mathrm{Ca}^{2+}$ inhibitors with greatly improved fluorescence properties. J. Biol. Chem. 260:3440-3450.

30. Beukers, M. W., Y. Oh, H. Zhang, N. Ling, and R. G. Rosenfeld. 1991. $\left[\mathrm{Leu}^{27}\right.$ ] insulin-like growth factor II is highly selective for the type-II IGF receptor in binding, cross-linking and thymidine incorporation experiments. Endocrinology. 128:1201-1203.

31. Stracke, M. L., J. D. Engel, L. W. Wilson, M. M. Rechler, L. A. Liotta, and 
E. Schiffmann. 1989. The type I insulin-like growth factor is a motility receptor in human melanoma cells. J. Biol. Chem. 264:21544-21549.

32. Minniti, C. P., E. C. Kohn, J. H. Grubb, W. S. Sly, Y. Oh, H. L. Möller, R. G. Rosenfeld, and L. J. Helman. 1992. The insulin-like growth factor II (IGFII)/mannose 6-phosphate receptor mediates IGF-II-induced motility in human rhabdomyosarcoma cells. J. Biol. Chem. 267:9000-9004.

33. Grant, M., J. Jerdan, and T. J. Merimee. 1987. Insulin-like growth factor-I modulates endothelial cell chemotaxis. J. Clin. Endocrinol. Metab. 65:370-371.

34. Shoji, S., R. F. Ertl, J. Linder, S.-I. Koizumi, W. C. Duckworth, and S. I. Rennard. 1990. Bronchial epithelial cells respond to insulin and insulin-like growth factor-I as a chemoattractant. Am. J. Respir. Cell. Mol. Biol. 2:553-555.

35. Grant, M. B., C. Guay, and R. Marsh. 1990. Insulin-like growth factor I stimulates proliferation, migration, and plasminogen activator release by human retinal pigment epithelial cells. Curr. Eye. Res. 9:323-335.

36. Nakao-Hayashi, J., H. Ito, T. Kanayasu, I. Morita, and S.-I. Murota. 1992. Stimulatory effects of insulin and insulin-like growth factor I on migration and tube formation by vascular endothelial cells. Atherosclerosis. 92:141-149.

37. Matsuda, N., W.-L. Lin, N. M. Kumar, M. I. Cho, and R. J. Genco. 1992. Mitogenic, chemotactic, and synthetic responses of rat periodontal ligament fibroblastic cells to polypeptide growth factors in vitro. J. Periodontol. 63:515-525.

38. Beckner, M. E., M. L. Stracke, L. A. Liotta, and E. Schiffmann. 1990. Glycolysis as primary energy source in tumor cell chemotaxis. J. Natl. Cancer Inst. 82:1836-1840.

39. Kohn, E. C., E. A. Francis, L. A. Liotta, and E. Schiffmann. 1990. Heterogeneity of the motility responses in malignant tumor cells: a biological basis for the diversity and homing of metastatic cells. Int. J. Cancer. 46:287-292.

40. Cunningham, C. C., T. P. Stossel, and D. J. Kwiatkowski. 1991. Enhanced motility in NIH 3T3 fibroblasts that overexpress gelsolin. Science (Wash. DC). 251:1233-1236.

41. Fukami, K., K. Furuhashi, M. Inagaki, T. Endo, S. Hatano, and T. Takenawa. 1992. Requirement of phosphatidylinositol 4,5-biphosphate for $\alpha$-actinin function. Nature (Lond.). 359:150-152.

42. Valius, M., and A. Kazlauskas. 1993. Phospholipase C- $\gamma 1$ and phosphatidylinositol 3 kinase are downstream mediators of the PDGF receptor's mitogenic signal. Cell. 73:321-334.
43. Martelli, A. M., R. S. Gilmour, V. Bertagnolo, L. M. Neri, L. Manzoli, and L. Cocco. 1992. Nuclear localization and signalling activity of phosphoinositidase $\mathrm{C} \beta$ in Swiss 3T3 cells. Nature (Lond.). 358:242-245.

44. Sun, X. J., E. Skolnik, M. G. Myers, B. Neel, J. Schlessinger, and M. F. White. 1993. Distinct insulin signals can be mediated through multiple phosphorylation of IRS-1. Exp. Clin. Endocrinol. 101(Suppl. 2):101-103.

45. Guse, A. H., W. Kiess, B. Funk, U. Kessler, I. Berg, and G. Gercken. 1992. Identification and characterization of insulin-like growth factor receptors on adult rat cardiac monocytes: Linkage to inositol 1,4,5-trisphosphate formation. Endocrinology. 130:145-151.

46. Takasu, N., M. Takasu, I. Komiya, Y. Nagasawa, T. Asawa, Y. Shimizu, and T. Yamada. 1989. Insulin-like growth factor I stimulates inositol phosphate accumulation, a rise in cytoplasmic free calcium, and proliferation in cultured porcine thyroid cells. J. Biol. Chem. 264:18485-18488.

47. Wood, K. W., C. Sarnecki, T. M. Roberts, and J. Blenis. 1992. Ras mediates nerve growth factor receptor modulation of three signal-transducing protein kinases: MAP kinase, Raf-1, and RSK. Cell. 68:1041-1050.

48. Blenis, J. 1993. Signal transduction via the MAP kinases: proceed at your own RSK. Proc. Natl. Acad. Sci. USA. 90:5889-5892.

49. Pavlovic-Surjancev, B., A. L. Cahill, and R. L. Perlman. 1992. Nicotinic agonists, phorbol esters, and growth factors activate two extracellular signal-regulated kinases, ERK1 and ERK2, in bovine chromaffin cells. J. Neurochem. 59:2134-2140.

50. Ray, L. B., and T. W. Sturgill. 1988. Characterization of insulin-stimulated microtubule-associated protein kinase. Rapid isolation and stabilization of a novel serine/threonine kinase from 3T3-Ll cells. J. Biol. Chem. 263:1272112727.

51. Skolnik, E. Y., A. Batzer, N. Li, C.-H. Lee, E. Lowenstein, M. Mohammadi, B. Margolis, and J. Schlessinger. 1993. The function of GRB2 in linking the insulin receptor to Ras signaling pathway. Science (Wash. DC). 260:1953-1955.

52. Banskota, N. K., R. Taub, K. Zellner, and G. L. King. 1989. Insulin, insulin-like growth factor I and platelet-derived growth factor interact additively in the induction of the protooncogene c-myc and cellular proliferation in cultured bovine aortic smooth muscle cells. Mol. Endocrinol. 3:1183-1190. 